\title{
PELATIHAN PEMASARAN, PEMBERDAYAAN TOKO ONLINE, DAN PENGENALAN $m$-commerce PADA PRODUK UNGGULAN JAGUNG TORTILA DI KECAMATAN TRUCUK KABUPATEN BOJONEGORO
}

\author{
Annysa Endriastuti, Maurisia Putri Permatasari \\ Fakultas Vokasi, Universitas Airlangga \\ Annysa.endri@vokasi.unair.ac.id
}

\begin{abstract}
In today's MEA (ASEAN economic community) era, the need to be more innovative in designing and marketing any products are necessary to those who run UMKM (Usaha Mikro Kecil dan Menengah). However, one particular factor that fully hinders them is the holistic marketing processes besides capital, technology, and human resources. To further implement the solution, this paper concentrates on both UMKM Makmur Asri and Tani Makmur (in Tulungrejo, Trucuk, Bojonegoro), the manufacturer of tortilla snack, as the firms facing the mentioned trouble. Located far from the surrounding main roads, their location is by chance hard to reach. For the reason of distant constraint to customers, one better strategy is to apply the use of online shop and introduce mcommerce model. Thus, by intensive training and mentoring, this iBM community service fills them in with all the details of the two combinations of marketing and English for business. It is with big hope that through applying this method can help the firms and their product be locally and internationally consumed and much more so.
\end{abstract}

Key words: marketing, online store, m-commerce, tortilla corn.

\begin{abstract}
Abstrak
Dalam menyongsong era MEA, para pelaku UMKM di Indonesia dituntut untuk semakin inovatif dalam mendesain dan memasarkan produk mereka. Kendala yang selama ini mereka hadapi, selain modal, teknologi rendah, dan kurangnya kualitas dan kuantitas SDM, adalah proses pemasaran yang belum menyeluruh. UMKM Makmur Asri dan Tani Makmur sebagai penghasil snack jagung tortilla di Desa Tulungrejo, Kecamatan Trucuk, Kabupaten Bojonegoro adalah contoh UMKM yang menghadapi permasalahan tersebut. Karena letaknya yang jauh dari jalan raya maka produk jagung ini sulit dijangkau oleh konsumen. Salah satu strategi yang dilakukan adalah melalui model pemasaran berbasis online shop (toko online) dan pengenalan terhadap model $\mathrm{m}$ commerce. Pelatihan dan pendampingan pun dilakukan sebagai upaya meningkatkan pengetahuan dan kualitas SDM di bidang pemasaran dan penguasaan bahasa asing (Bahasa Inggris) dalam media. Hasil yang diharapkan adalah adanya pemasaran produk yang tidak hanya terbatas pada area lokal melainkan juga dikenal secara nasional dan bahkan internasional.
\end{abstract}

Kata kunci: pemasaran, toko online, m-commerce, jagung tortilla. 


\section{PENDAHULUAN}

Berdasarkan data yag diperoleh dari Badan Pusat Statistik, Kabupaten Bojonegoro terletak pada $111,25^{\prime}$ dan 112,09' Bujur Timur serta 6,59' dan 7,37' Lintang Selatan. Secara geografis, wilayah ini berbatasan dengan Kabupaten Tuban (sebelah utara), Kabupaten Madiun, Nganjuk, dan Jombang (sebelah selatan), Kabupaten Ngawi dan Blora (sebelah barat), serta Kabupaten Lamongan (sebelah timur). Luas wilayah Kabupaten Bojonegoro sebesar 230.706 hektar dengan pembagian lahan non-pertanian seluas 94.836 hektar, lahan kering 42.412 hektar, lahan sawah 77.238 hektar, perkebunan 27 hektar, hutan 2.051 hektar dan lainnya 58,636 hektar. Berdasarkan segi topografisnya, di sepanjang daerah aliran Sungai Bengawan Solo merupakan daerah dataran rendah (low land) yang berada pada ketinggian 25 meter dengan kemiringan $2 \%$ sampai $14,99 \%$, sedangkan di bagian selatan merupakan dataran tinggi (upland plain) yaitu sepanjang kawasan Gunung Pandan, Kramat, dan Gajah yang berada pada ketinggian di atas 25 meter.

Kabupaten Bojonegoro terbagi dalam 28 Kecamatan, 11 kelurahan, dan 419 desa dengan jumlah penduduk mencapai 1.209 .334 jiwa di mana $70 \%$ di antaranya berkecimpung di bidang pertanian. Kabupaten ini merupakan daerah aliran sungai (DAS) Bengawan Solo dan hampir setiap wilayah yang dilalui aliran sungai ini seringkali terendam banjir. DAS Bengawan Solo yang terdapat di Kabupaten Bojonegoro merupakan bagian tengah DAS Bengawan Solo yang rawan terjadi pengendapan sebagai hasil erosi dari daerah hulu. Meskipun demikian, menurut Agustono dkk, (2010) daerah rawan banjir seperti Kabupaten Bojonegoro telah berhasil mengidentifikasi komoditi-komoditi unggulan di Bojonegoro, salah satunya adalah komoditi jagung. Komoditi jagung terbesar di Bojonegoro berada di Kecamata Trucuk. Hasil produksi jagung di wilayah ini mencapai 90.000 ton/tahun yang kemudian diolah menjadi berbagai macam jenis makanan, salah satunya keripik jagung yang dikenal dengan nama Jagung Tortilla. Dengan proses pengolahan yang relatif mudah, usaha ini banyak berkembang di sektor industri rumah tangga (home industry) yang mayoritas dikerjakan oleh para wanita dan ibu-ibu rumah tangga.

Pada dasarnya, salah satu upaya dalam mengembangkan perekonomian warga adalah melalui pengolahan potensi alam yang dimiliki oleh masyarakat sekitar sebagai bahan baku menjadi barang jadi melalui aktivitas industri. Pembangunan kawasan sentra industri merupakan salah satu upaya membangun perekonomian lokal yang bertujuan untuk membangun produksi berbasis komoditas unggulan yang dimiliki oleh masyarakat setempat melalui kerjasama antara pemerintah dan swasta (Supriyadi, 2007). Lebih lanjut menurut Buku Acuan Penerapan Pengembangan Ekonomi Lokal untuk Kota dan Kabupaten (Rahma, 2012) memaparkan bahwa konsep Pengembangan Ekonomi Lokal (PEL) memberi penekanan pada pemanfaatan secara maksimal terhadap sumber daya, kapasitas dan keterampilan yang ada di daerah. PEL didefinisikan sebagai suatu kerjasama yang terjalin antara pemerintah, dunia usaha, serta sektor non pemerintah dan masyarakat untuk mengidentifikasi dan juga memanfaatkan sumber daya lokal yang dimiliki daerah guna mengoptimalkan 
Annysa Endriastuti, dkk. Pelatihan Pemasaran, Pemberdayaan Toko Online...

dan menciptakan perekonomian lokal yang lebih baik dan lebih kuat dari sebelumnya.

Selama ini Kecamatan Trucuk, Kabupaten Bojonegoro dikenal sebagai sentra tortilla yang sangat potensial. Salah satu kelompok usaha yag melakukan pengolahan jangung tortilla adalah Kelompok Wanita Makmur Asri diketuai oleh Ibu Tri Tugas Luh Untari (Ibu Untari). Kelompok Wanita Makmur Asri saat ini mampu memproduksi tortilla per hari rata-rata sebanyak 50-75 kg jagung. Pemasaran jagung tortilla saat ini masih berada di sekitar wilayah Bojonegoro, Lamongan, Mojokerto, dan beberapa wilayang di sekitarnya. Proses produksi yang dilakukan oleh kelompok usaha ini ditunjang dengan ketersediaan bahan baku jagung lokal yang melimpah. Di sisi lain, kelompok Tani Makmur yang banyak menangani proses produksi jagung bertugas sebagai pemasok utama bahan baku jagung yang digunakan oleh kelompok Makmur Asri dalam proses produksi jagung tortilla. Kelompok tani Tani Makmur beranggotakan 43 orang petani, terdiri dari 35 orang laki-laki dan 8 orang wanita. Produksi jagung rata-rata per tahun dari kelompok Tani Makmur sebesar 7 ton dan per Ha ratarata mampu menghasilkan produksi jagung sebanyak $7500 \mathrm{~kg}$ jagung pipilan kering. Varietas jagung yang dibudidayakan di desa Tulungrejo adalah varietas hibrida dengan umur tanam 105-115 hari.

Meskipun demikian, model pemasaran yang dilakukan oleh kedua kelompok usaha tersebut masih tergolong konvensional (memiliki toko offline) dan belum memaksimalkan penggunaan IPTEK yang berbasis media online (toko online) dimana pergerakannya dinilai lebih cepat dan luas dibandingkan toko offline. Oleh sebab itu, perlu dibangun suatu program pemasaran yang berbasis pada pengelolalaan IPTEK yang tepat guna untuk meningkatkan omset penjualan, sehingga mampu meningkatkan kesejahteraan anggota kelompok dalam segi finansial.

Dalam proses pemasaran jagung tortilla, kelompok usaha Makmur Asri masih menghadapi berbagai macam kendala, diantaranya: 1) Kelompok usaha Makmur Asri telah menggunakan merk 'Makmur Asri' untuk melabeli hasil produksi jagung tortilla-nya, sama dengan nama Usaha Dagang (UD) yang terdaftar. Namun, produknya belum memiliki konsep kemasan yang marketable dan tahan lama agar terlihat lebih higienis dan menarik. 2) Kelompok usaha ini memiliki target ingin memperluas pemasaran usahanya sampai ke Jawa tengah, Jawa Barat, dan di luar pulau Jawa bahkan di pasar internasional. Namun, konsep usaha toko online belum dipahami secara baik sehingga lebih menekankan pada aktivitas usaha offline saja yang dirasa kurang efektif dan efisien. 3) Sebenarnya produk tortilla ini telah memiliki ijin dari Departemen Kesehatan namun belum dimanfaatkan secara maksimal dalam pengemasan yang bervariasi untuk menarik pembeli. 4) Sehubungan dengan pembukaan toko online, yang berbasis pada penggunaan telepon genggam perlu dikenalkan untuk mempertajam pemasaran produk di kawasan internasional termasuk pada penggunaan fitur-fitur berbahasa Inggris. Pada tataran ini, banyak anggota kelompok yang memiliki telepon seluler berbasis Android namun belum menguasai teknologi secara tepat guna dan belum memiliki kemampuan menggunakan bahasa asing (Bahasa Inggris) sehingga menghambat pemasaran produk. 5) Di area ini sebenarnya banyak sekali usaha rumahan yang memproduksi jagung 
tortila, namun banyak di antaranya yang gulung tikar dan memutuskan untuk menutup usahanya, sehingga pemahaman tentang m-commerce (mobile commerce) perlu diperkenalkan sebagai upaya untuk menstimulus para pelaku usaha untuk menggerakkan usahanya kembali.

Beberapa permasalahan di atas membutuhkan solusi. Adapun solusi yang ditawarkan antara lain: 1) melakukan pelatihan dan pendampingan kepada seluruh anggota kelompok UMKM Makmur Asri dan Tani Makmur yang berkaitan dengan penetapan target pasar dan pengemasan produk. 2) pelatihan dan pendampingan yang berkaitan dengan pembuatan toko online dan pengenalan m-commerce dalam pemasaran produk. 3) Pelatihan pengenalan istilah-istilah dan fitur-fitur Bahasa Inggris dalam media internet untuk produk tortilla.

\section{METODE PELAKSANAAN}

Untuk menjawab permasalahan yang dihadapi mitra dan merealisasikan solusinya, maka dilakukan beberapa kegiatan sebagai berikut : 1) Persiapan: pada tahap ini dilakukan ijin lokasi yang ditujukan kepada kepala desa dan camat Kecamatan Trucuk beserta perangkatnya serta dilakukan survei kepada kelompok usaha Tani Makmur dan Makmur Asri. 2) Sosialisasi Program: sebelum dilaksanakannya pelatihan dan pendampingan pemasaran online berbasis m-commerce, terlebih dahulu dilakukan sosialisasi kepada para anggota kedua kelompok tentang proses dan manfaat diadakannya program pengabdian masyarakat ini, sehingga akan menggerakkan antusiasme para anggotanya agar mau bergabung dan ikut melaksanakan program-program yang telah direncanakan. 3) Pelatihan: Pelatihan yang akan dilaksanakan meliputi beberapa sub materi, diantaranya: a) Pelatihan pemasaran produk (meliputi penentuan target pasar dan pengemasan produk) membuka b) Pelatihan pembukaan toko online serta pengenalan media online berbasis $m$ commerce; c) Pengenalan istilah-istilah dan fitur-fitur berbahasa Inggris pada media online. 4) Pelaksanaan: dalam kegiatan ini kelompok sasaran diharapkan: a) Berpartisipasi dan berperan aktif dalam sosialisasi program kegiatan; b) Berpartisipasi dan berperan aktif dalam pelatihan yang telah direncanakan; c) Berpartisipasi dan berperan aktif dalam mengikuti program pembuatan toko online baik yang bercorak lokal, nasional, maupun internasional; d) Berpartisipasi dan berperan aktif dalam menggunakan istilah-istilah dan fitur-fitur online berbahasa Inggris; e) Berpartisipasi dan berperan aktif dalam mempelajari target pasar dan pengemasan produk.

\section{HASIL DAN PEMBAHASAN}

\section{Target Pasar dan Pengemasan Produk Jagung Tortilla}

Strategi pemasaran modern didasarkan pada tiga pilar penting, antara lain: segmenting (segmentasi pasar), targeting (penetapan sasaran pasar), dan positioning (penetapan posisi pasar) (Kotler, 1995). Segmenting lebih ditujukan untuk membagi pasar menjadi kelompok-kelompok pembeli yang menyebabkan mereka membeli produk yang sama. Targeting merupakan suatu tindakan mengevaluasi keaktifan daya tarik setiap segmen pasar dan memilih salah satu atau lebih dari segmen pasar tersebut untuk dimasuki. Sedangkan positioning adalah tindakan untuk menempatkan posisi bersaing produk dan bauran pemasaran yang tepat pada 
Annysa Endriastuti, dkk. Pelatihan Pemasaran, Pemberdayaan Toko Online...

setiap pasar sasar. Ketiga pilar tersebut memiliki keterkaitan dalam proses pemasaran produk yang akan menentukan hasil penjualannya dalam kurun waktu tertentu. Pada pelatihan penentuan target pasar, para peserta diajak menganalisa segmen-segmen yang ada di pasar sehingga dapat menentukan pasar mana yang akan mereka masuki serta menentukan tindakan apa saja yang harus dilakukan untuk memasarkan produk mereka di pasar tersebut.

Produk snack tortilla selama ini banyak dikonsumsi oleh orang dewasa daripada kelompok muda. Hal ini didasarkan pada rasanya yang masih klasik. Belum adanya variasi rasa menjadikan produk ini terbatas pada pasar tertentu. Padahal, produk tortilla ini sebenarnya mampu memasuki beberapa segmen pasar, misalnya saja kelompok remaja atau anak-anak dengan menambahkan varian rasa yang banyak digemari oleh golongan tersebut. Sayangnya keterbatasan modal, sumber daya manusia, teknologi, dan pengetahuan menjadikan jajanan ini hanya didistribusikan pada kelompok tertentu saja dan berimbas pada minimnya pendapatan. Oleh karena itu, perlu pelatihan lebih lanjut yang memberikan ketrampilan kepada para anggota UMKM pembuat snack jagung tortilla tentang varian rasa dalam snack jagung tortilla.

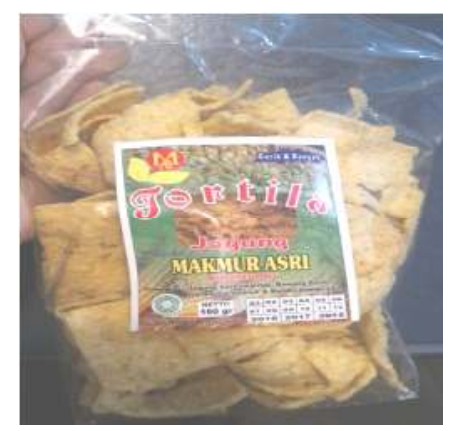

Gambar 1: Kemasan snack jagung tortilla Bojonegoro

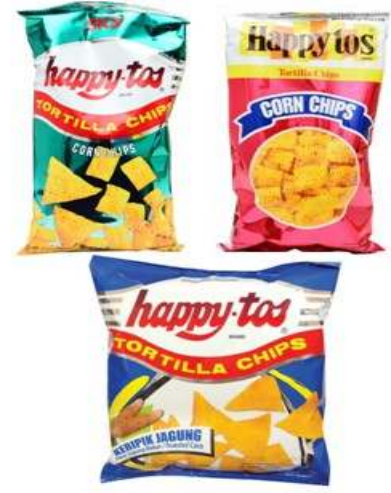

Gambar 2: Kemasan snack jagung tortilla di pasaran

Gambar 1 di atas merupakan contoh kemasan snack jagung tortilla yang diproduksi oleh kelompok UMKM Makmur Asri. Jika diamati, kemasan produk tortilla tersebut sangat sederhana. Kemasan yang digunakan berupa plastik tebal yang belum diisi dengan udara sehingga rawan guncangan dan mengakibatkan isi hancur dalam proses pengiriman. Sebenarnya, produsen bisa menggunakan alat pengisi udara (airfilling sealer) untuk meminimalisir kerugian karena barang hancur.

Di sisi lain, nama yang digunakan juga masih menggunakan nama Usaha Dagang (UD) yang dimiliki oleh UMKM tersebut. Hal ini tentu saja kurang menarik konsumen karena dianggap jajanan yang kurang enak dan tidak modern. Jika dibandingkan dengan kemasan snack jagung tortilla yang ada di pasar lainnya (gambar 2), jelas sekali dari sisi kemasan snack jagung tortilla yang diproduksi oleh UMKM Makmur Asri kalah bersaing. Oleh sebab itu, perlu adanya perubahan yang berkaitan dengan nama dan kemasan produk agar mudah diingat, menarik konsumen, dan aman ketika didistribusikan. 


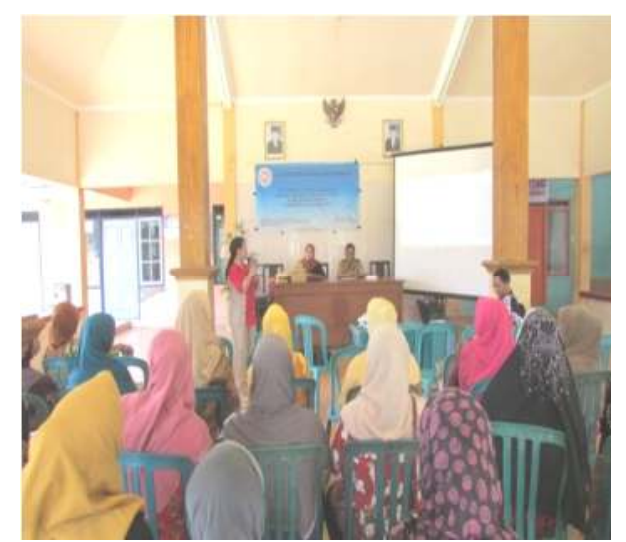

Gambar 3: Pelatihan penentuan target pasar dan pengemasan snack jagung tortilla

\section{Pelatihan Pembukaan Toko Online dan pengenalan m-commerce bagi UMKM Jagung Tortilla}

Toko online (online store) dapat didefinisikan sebagai tempat terjadinya aktivitas perdagangan atau jual beli barang yang terhubung ke dalam suatu jaringan yang dikenal dengan jaringan internet (Yusuf, 2012). Pembeli dapat mengunjungi toko online kapan saja (tidak terbatas waktu) dan membeli produk yang tersedia dalam media internet. Bila di toko biasa (offline store) pembeli dilayani oleh manusia, maka pada toko online pembeli akan dilayani oleh mesin. Proses jual beli semacam ini dirasa lebih efektif dalam memperkenalkan produk dan memasarkannya.

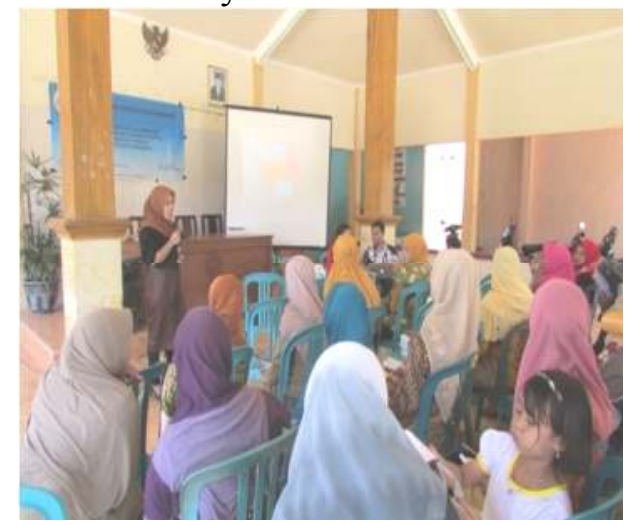

Gambar 4: Pelatihan pembukaan toko online
Bagi para penjual, membuka toko online memiliki beberapa keuntungan, diataranya: toko online akan diakses oleh orang-orang yang sedang mencari barang yang dijual di toko tersebut (tepat sasaran), modal rendah, dapat dilakukan oleh siapa saja, toko dapat dibuka selama 24 jam dengan proses pembelian yang berjalan secara otomatis, penjual tidak perlu menimbun stok dan tidak membutuhkan banyak karyawan untuk mengurus dan menjaga barang, biaya promosi murah, dapat dijalankan di mana saja, pasar yang dijangkau lebih luas, serta memiliki potensi penghasilan yang besar.

Beberapa keuntungan di atas juga tidak terlepas pada kelemahan yang dimiliki oleh toko online, diantaranya: adanya resistensi sekelompok orang terhadap barang yang dijual secara online karena seringkali terdapat perbedaan antara produk asli dengan produk yang dipajang dalam toko online (efek kamera dll), proses pembayaran yang sedikit rumit, pasar yang dituju memang bersifat global namun hanya terbatas pada pengguna internet yang umumnya kelompok muda, adanya tambahan biaya pengiriman barang, apabila barang dianggap tidak sesuai pesanan, maka sistem komplain akan sedikit rumit. Meskipun memiliki beberpa kelemahan, namun toko online memiliki manfaat praktis bagi para penjual yang ingin memperluas bisnis dengan modal kecil.

Strategi penjualan melalui toko online tersebut perlu dicoba oleh produsen snack jagung tortilla untuk memperluas pemasaran. Desa Tulungrejo merupakan daerah penghasil jagung terbesar di Kecamatan Trucuk. Sebagai sentra pengolahan jagung tortilla, lokasi desa ini cukup jauh dari jalan raya. Oleh karenanya, sulit sekali bagi konsumen untuk menjangkau area 
Annysa Endriastuti, dkk. Pelatihan Pemasaran, Pemberdayaan Toko Online...

tersebut. Mereka biasa mendistribusikan produk mereka ke toko-toko maupun swalayan kecil di sekitar area Bojonegro. Dengan membuat toko online, maka produsen snack tortilla dapat memperkenalkan produk mereka kepada masyarakat luas tanpa perlu membuka toko di depan rumah. Langkah ini menjadi solusi yang cukup menjanjikan dalam mengatasi permasalahan mitra di bidang pemasaran produk. Karena akhir-akhir ini orang cenderung memilih toko online dalam membeli barang karena dianggap lebih praktis.

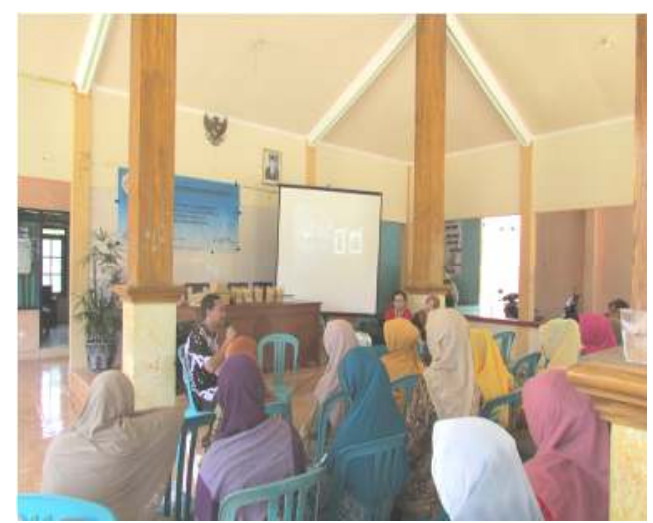

Gambar 5: Pengenalan m-commerce

Dalam pelatihan membuat toko online, pertama-tama peserta dikenalkan dengan pengertian, manfaat, dan beberapa contoh nama toko online yang telah dikenal masyarakat luas. Kemudian, peserta diajarkan untuk membuat email sebagai portal untuk mengakses ke beberapa website $e$ commerce yang ada (misalnya: bukalapak, tokopedia, dll) serta untuk membuka toko online melalui media sosial seperti facebook dan instagram. Pembuatan toko online yang diajarkan ditujukan pada pembuatan toko online gratis sehingga menekan biaya promosi.

Seiring dengan perkembangan zaman di mana transaksi jual beli tidak hanya dilakukan di satu tempat saja, maka para peserta dikenalkan dengan penggunaan $m$-commerce. M-commerce (Mobile commerce) merupakan transaksi dan komunikasi elektronik yang dilakukan dengan menggunakan mobile (seperti: laptop, PDA, telepon seluler dll) dan pada umumnya menggunakan koneksi nirkabel (Chaffey, 2011) . Beberapa orang memaknai $m$-commerce sebagai $e$ commerce yang berada pada jaringan nirkabel.

M-commerce dikenalkan kepada mitra mengingat adanya pergeseran tren masyarakat yang semakin intens dalam menggunakan telepon genggam. Hal ini menjadi peluang yang sangat besar apabila diaplikasikan dalam proses jual beli produk. Dalam cara kerjanya, $m$ commerce memiliki beberapa tahapan proses, diantaranya: 1) set-up dan konfigurasi: meliputi proses instalasi tertentu pada handset yang akan dioperasikan dalam m-commerce, tahapan ini berkaitan juga dengan pembelian atau penambahan nilau uang pada aplikasi. 2) instalasi pembayaran: pembayaran dilakukan melalui jaringan seluler (atau protokol wireless lainnya) kepada pemilik produk. 3) autentikasi: mengarah pada tahapan yang paling krusial di mana pada fase ini ditentukan apakah pengguna berhak dan memenuhi persyaratan finansial untuk melakukan transaksi. 4) Penyelesaian pembayaran: tahap ini merupakan kondisi di mana ketika transaksi dapat diautentikasi. Dalam tahapan-tahapan di atas, beberapa pihak terkait di dalamnya, antara lain: pengguna (pembeli), operator jaringan, institusi finansial dan merchant (penyedia produk atau jasa yang akan dibeli).

Melihat semakin tingginya pengguna telepon seluler berbasis android (smartphone) di Indonesia menjadi suatu hal yang menjanjikan bagi perkembangan $m$-commerce di tanah air. Selain itu, murahnya harga 
smartphone di pasar dapat meningkatkan jumlah pengguna yang nantinya akan membantu pertumbuhan m-commerce. Salah satu merchant yang berhasil meningkatkan penjualannya hingga $25 \%$ melalui aplikasi mobile adalah Zalora. Oleh karenanya, model penjualan semacam ini perlu digerakkan sebagai upaya membantu para konsumen melakukan transaksi tanpa dibatasi waktu dan lokasi. Di sisi lain, peningkatan penghasilan konsumen juga akan terus bertambah sebagai akibat dari proses transaksi praktis yang ditawarkan.

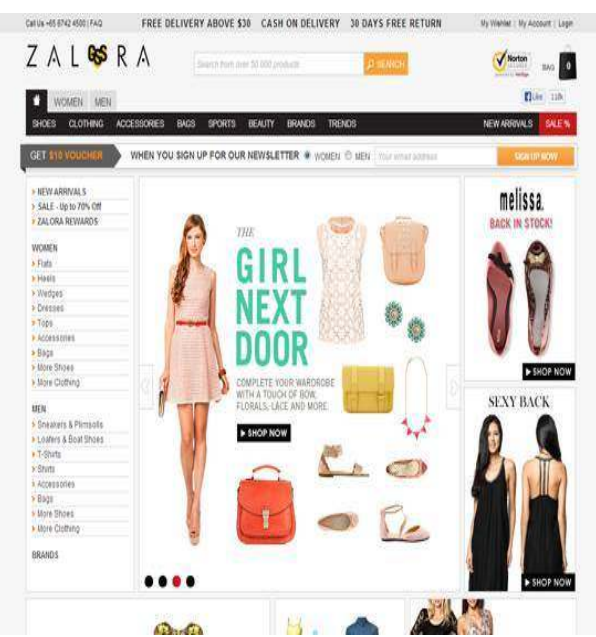

Gambar 6: Zalora, salah satu merchant yang menggunakan $m$-commerce

Pengenalan m-commerce kepada para pelaku UMKM, salah satunya UMKM jagung tortilla, diharapkan dapat melahirkan semangat baru dalam berbisnis agar para produsen lokal memiliki atmosfer perputaran transaksi perdagangan berbasis telepon seluler layaknya di negara Cina dan Korea Selatan. M-commerce dapat dibangun untuk meningkatkan penjualan produkproduk lokal yang dikumpulkan menjadi satu wadah dalam aplikasi website dan diakses menggunakan smartphone.
Akan sangat menarik apabila seluruh hasil produk lokal Bojonegoro, seperti: jagung tortilla, batik, ukiran kayu jati dan beberapa produk lainnya dapat ditampilkan dalam model m-commerce. Masyarakat dunia berkesempatan untuk membeli produk tersebut hanya dengan menggerakkan jari-jari mereka di atas smartphone. Dan pada akhirnya, produk lokal Bojonegoro dapat dikenal secara luas dan berimplikasi pada kenaikan kesejahteraan para anggota UMKM yang terlibat di dalamnya. Meskipun demikian, berbagai kendala masih dihadapi dalam menggunakan $m$ commerce. Belum siapnya varian produk, kualitas produk yang tidak terkontrol, kualitas SDM yang rendah, jaringan internet yang belum memadahi, serta beberapa permasalahan lainnya menjadi penghalang dalam penerapan model tersebut. Oleh karenanya, berbagai macam pelatihan dan pendampingan baik dari pemerintah, tokoh masyarakat, akademisi, dan berbagai kelompok masyarakat yang lainnya masih sangat diperlukan guna mencapai peningkatan mutu secara komprehensif.

Pengenalan Istilah dan Fitur Bahasa Inggris dalam Media Internet bagi Pelaku UMKM

Sebagai bahasa internasional, Bahasa Inggris menjadi sangat penting bagi sebagian besar masyarakat di dunia. Hal ini juga termasuk penggunaan Bahasa Inggris dalam media internet, begitu pula dalam bisnis online. Dalam pelatihan, para peserta dikenalkan dengan beberapa istilah yang sering digunakan dalam transaksi online, antara lain: 
Annysa Endriastuti, dkk. Pelatihan Pemasaran, Pemberdayaan Toko Online...

Tabel 1: Istilah Dalam Jual Beli Online

\begin{tabular}{|c|c|c|c|}
\hline seller & $\begin{array}{l}\text { penjual/pemilik toko } \\
\text { online }\end{array}$ & Sold & Barang habis terjual \\
\hline buyer & Pembeli & Trusted & Terpercaya, bukan penipu \\
\hline customer & $\begin{array}{l}\text { Sebutan untuk pembeli } \\
\text { yang loyal }\end{array}$ & Testimonial & $\begin{array}{l}\text { pesan dan kesan dari pelanggan. Ini } \\
\text { biasanya dijadikan bukti untuk } \\
\text { meyakinkan pembeli lainnya } \\
\text { berdasarkan pengakuan pembeli } \\
\text { sebelumnya. }\end{array}$ \\
\hline supplier & $\begin{array}{l}\text { Pemasok barang pada } \\
\text { penjual }\end{array}$ & $\begin{array}{l}\text { DP (Down } \\
\text { Payment })\end{array}$ & $\begin{array}{l}\text { sistem pembayaran yang tidak } \\
\text { langsung dibayar lunas. Sistem } \\
\text { pembayaran ini biasanya digunakan } \\
\text { untuk barang dengan sistem pre } \\
\text { order. }\end{array}$ \\
\hline Reseller & $\begin{array}{l}\text { Penjual yang menjual } \\
\text { barang orang lain untuk } \\
\text { konsumennya (bisa } \\
\text { disebut calo) }\end{array}$ & Full payment & Pembayaran penuh (lunas) \\
\hline Dropship & $\begin{array}{l}\text { Pengiriman barang } \\
\text { kepada konsumen dengan } \\
\text { mengatasnamakan pihak } \\
\text { kedua selaku reseller }\end{array}$ & Booked & $\begin{array}{l}\text { Produk telah dipesan sehingga } \\
\text { konsumen lainnya tidak dapat } \\
\text { membelinya }\end{array}$ \\
\hline $\mathrm{TF}$ & Transfer & Кeер & $\begin{array}{l}\text { Hampir sama dengan booked di } \\
\text { atas, keep biasanya dilakukan oleh } \\
\text { pembeli yang sudah pasti akan } \\
\text { membeli satu produk tapi belum } \\
\text { sempat melakukan pembayaran. Hal } \\
\text { ini dilakukan agar barang tidak } \\
\text { terjual kepada orang lain. }\end{array}$ \\
\hline Return & $\begin{array}{l}\text { Penukaran barang yang } \\
\text { sudah dibeli dengan } \\
\text { barang yang lain }\end{array}$ & hit and run & $\begin{array}{l}\text { Istilah bagi konsumen yang } \\
\text { memesan barang tapi tidak } \\
\text { menepati janji untuk membayar }\end{array}$ \\
\hline Refund & $\begin{array}{l}\text { Transaksi dibatalkan, } \\
\text { barang dikembalikan } \\
\text { kepada penjual dan uang } \\
\text { dikembalikan kepada } \\
\text { pembeli }\end{array}$ & Shipping cost & $\begin{array}{l}\text { Biasa disebut dengan ongkir } \\
\text { (ongkos kirim). Biaya kirim yang } \\
\text { dibebankan kepada pembeli }\end{array}$ \\
\hline Reject & $\begin{array}{l}\text { Barang tidak dalam } \\
\text { kondisi baik, ada cacat }\end{array}$ & $\begin{array}{l}\text { Cash on } \\
\text { Delivery } \\
\text { (COD) }\end{array}$ & $\begin{array}{l}\text { Transaksi jual beli produk di mana } \\
\text { antara penjual dan pembeli saling } \\
\text { bertemi di tempat yang telah } \\
\text { disepakati. }\end{array}$ \\
\hline $\begin{array}{l}\text { Ready } \\
\text { stock }\end{array}$ & Barang tersedia & $\begin{array}{c}P O \\
(\text { Pre-Order) }\end{array}$ & $\begin{array}{l}\text { Sistem yang banyak dipakai untuk } \\
\text { menjual barang impor atau custom. } \\
\text { Jadi, barang baru akan dipesankan } \\
\text { atau diproduksi setelah jadwal PO } \\
\text { berakhir dan dikirim setelah barang } \\
\text { jadi. }\end{array}$ \\
\hline restock & $\begin{array}{l}\text { Barang yang stoknya } \\
\text { telah habis habis tersedia } \\
\text { kembali }\end{array}$ & Out of stock & $\begin{array}{l}\text { Barang yang habis persediannya } \\
\text { baik pada penjual maupun suppier }\end{array}$ \\
\hline
\end{tabular}

Sumber: http://www.onino.web.id/2014/09/27-istilah-dalam-jual-beli-online.html 


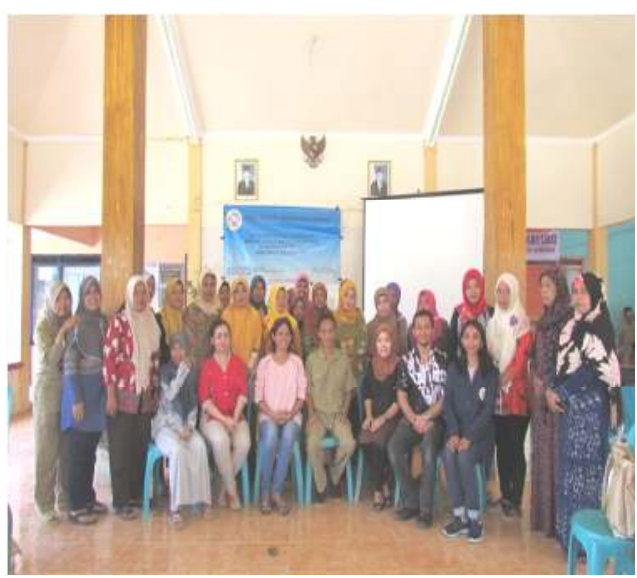

Gambar 7. Peserta pelatihan

Selain itu, peserta pelatihan juga dikenalkan dengan fitur-fitur utama $m$ commerce yang menggunakan Bahasa Inggris, meliputi: a) Jam pick-up, waktu bagi konsumen untuk bisa memesan. b) Start order, saat konsumen bisa mulai memesan. c) Choose items, konsumen memastikan jenis dan harga produk, serta jumlah pesanan. Selain itu dikenal juga fitur Dish details (jumlah pesanan dari suatu jenis produk) yang meliputi: 1) Quantity: jumlah pesanan dan 2) Special note: berisi catatan konsumen terkait produk yang dipesan (apakah karena bentuk, rasa, atau warna). Kemudian terdapat fitur cancel order, kepastian bagi konsumen apakah akan membatalkan pembelian atau membeli produk. Selanjutnya, dikenal fitur-fitur pendukung lainnya, meliputi: a) order later, saat toko online tetap buka untuk memastikan pesanan tidak pada waktunya b) confirm date \& time, bagi konsumen untuk memastikan tanggal dan jam pesanan diantar.

\section{SIMPULAN}

Tumbuh kembang UMKM di Indonesia perlu mendapatkan perhatian khusus dari seluruh kalangan masyarakat. Perhatian tersebut dapat diwujudkan dalam bentuk dukungan dan pelatihan ketrampilan. Salah satu aktivitas para akademisi Universitas Airlangga adalah dengan melakukan kegiatan Pengabdian kepada Masyarakat melalui skema Iptek bagi Masyarakat (IbM). Program ini bertujuan untuk membantu meningkatkan kesejahteraan para penggerak UMKM dalam pengelolaan usahanya.

UMKM yang didirikan oleh Kelompok Wanita Makmur Asri dan Tani Makmur di Desa Tulungrejo, Kecamatan Trucuk, Kabupaten Bojonegoro merupakan salah satu contoh UMKM yang memerlukan pendampingan dalam pengelolaan usaha. Sebagai salah satu produsen snack jagung tortilla, UMKM ini masih menghadapi berbagai macam kendala baik di dalam permodalan, peralatan berbasis teknologi, serta pemasaran dan pendistribusian barang. Oleh sebab itu, perlu adanya langkah-langkah penyelesaian masalah sebagai usaha untuk meningkatkan kesejahteraan para anggota kelompok.

Dalam program PENGMAS ini, tim Universitas Airlangga memberikan pelatihan kepada Kelompok Wanita Makmur Asri dan Tani Makmur tentang target pasar dan packaging (pengemasan) produk, media online dan pembuatan toko online, serta pengenalan m-commerce dalam pemasaran dan pendistribusian barang. Selain itu, tim juga memberikan beberapa alternatif solusi atas permasalahan yang dihadapi terkait penggunaan Bahasa Inggris dalam pemasaran online terkait dengan pengenalan penggunaan istilah-istilah dan fitur-fitur berbahasa Inggris dalam transaksi online. Diharapkan dengan adanya kegiatan ini dapat membantu para penggerak UMKM dalam meningkatkan pendapatkan dan kesejahteraan hidup. Selain itu, harapan yang tebih besar ditujukan pada 
Annysa Endriastuti, dkk. Pelatihan Pemasaran, Pemberdayaan Toko Online...

pemasaran lintas negara, di mana barang-barang lokal dapat dikonsumsi oleh masyarakat internasional. Melalui potensi yang dimiliki oleh produkproduk lokal diharapkan masyarakat Indonesia tidak hanya menjadi penonton, melainkan menjadi yang ditonton dalam menyongsong era Masyarakat Ekonomi ASEAN (MEA).

\section{DAFTAR PUSTAKA}

Agustono, Setyowati, N, Rahayu, W, Barokah, U. 2010. Strategi Pengembangan Komoditi Pertanian Unggulan Di Daerah Rawan Banjir Dalam Rangka Mendukung Keberhasilan Otonomi Daerah Di Bojonegoro (Pendekatan Tipologi Klassen Dan QSPM (Quantitative Strategic Planning Matrix ). Penelitian Strategis Nasional. Tidak dipublikasikan.
Chaffey, D. 2011. E-Business dan Ecommerce Management: Strategi, Implementation, and Practice $\left(5^{\text {th }}\right)$. New Jersey: Person Education.

Kotler, Philip. 1995. Marketing Jilid II. Jakarta: Erlangga.

Supriyadi, Edy. 2007 Telaah Kendala Penerapan Pengembangan Ekonomi Lokal : Pragmatisme Dalam Praktek Pendekatan PEL. Jurnal Perencanaan Wilayah dan Kota, 18 (2): 103 123.

Rahma, Hania. 2012. Buku Acuan Penerapan Pengembangan Ekonomi Lokal untuk Kota dan Kabupaten. Jakarta, Direktorat Jenderal Cipta Karya, Kementerian Pekerjaan Umum.

Yusuf, Muhammad dan Yusuf, Achmad. 2012. 1 Jam Membuat Toko Online dengan JoomlaVirtuemart. Yogyakarta: Expert 